\title{
DEVELOPING STUDENT WORKSHEET BASED ON MISSOURI MATHEMATICS PROJECT MODEL BY USING THINK-TALK-WRITE STRATEGY OF CLASS VIII
}

\author{
Reny Wahyuni ${ }^{* 1}$, Efuansyah², Sukasno ${ }^{3}$ \\ ${ }^{1,2,3}$ STKIP PGRI Lubuklinggau
}

\section{Article Info \\ Article history: \\ Received Nov 232019 \\ Revised Jan 29, 2020 \\ Accepted Feb 2, 2020}

Keywords:

Missouri Mathematics Project, Student Worksheet, Think Talk Write Strategy, 4-D

\begin{abstract}
This study aims to develop the worksheet based Learning Model Missouri Mathematics Project using Think Talk Write Strategy on cube and cuboid material, and to find out the quality of the worksheet developed in terms of validity and practicality. Subjects in this study are students of class VIII SMP N 11 Lubuklinggau in the even semester of the 2018/2019 school year. This research is a development research that refers to the 4-D development model (Define, Design, Develop, and Disseminate). Based on the analysis results, it was found that the quality of worksheets developed was based on the assessment of 3 validators, the validity aspect was in the Good category with an average score of 3.99 , while the quality of worksheets from the practical aspect was in the Very Practical category with an average score of 0.903 .
\end{abstract}

Copyright $@ 2020$ IKIP Siliwangi. All rights reserved.

\section{Corresponding Author:}

Reny Wahyuni,

Department of Mathematics Education,

STKIP PGRI Lubuklianggau,

Jl. Mayor Toha, Air Kuti, Lubuklinggau, South Sumatera 31625, Indonesia.

Email: renywahyuni264@gmail.com

\section{How to Cite:}

Wahyuni, R., Efuansyah, E., \& Sukasno, S. (2020). Developing student worksheet based on missouri mathematics project model by using think-talk-write strategy of class VIII. Infinity, 9(1), 81-92.

\section{INTRODUCTION}

A student can be said to think critically if the student is able to test his experience, evaluate knowledge, ideas, and consider arguments before getting justification (Ismaimuza, 2011). The ways to build students' critical thinking are developed the attitudes of students' reasoning, be challenged, and seek the truth. Garrison, Anderson, \& Archer (2001) states that when critical thinking is developed, a person will tend to seek the truth, think openly and be tolerant of new ideas, be able to analyze problems well, think systematically, be curious, mature in think, and have crititical thinking independently. Mathematical critical thinking skills are very important for students because by mastering these abilities, students are able to be realistic and able to make good decisions for themselves (Jumaisyaroh, Napitupulu, \& Hasratuddin, 2014). In addition, critical thinking skills also need to be instilled early to students so students can solve various problems related to daily life (Somakim, 2011). When someone has the ability to think critically well, then he is not 
easy to believe about something without proving it first so that the information is valid and can be trusted (Fithriyah, Sa'dijah, \& Sisworo, 2016).

One way that teachers can do to improve the quality of mathematics lessons is to develop a teaching material (Sandiyanti, 2018). Teaching material is an important tool for teachers and students. Teachers will experience difficulties in providing mathematics learning to students without having complete teaching material, and students will also experience the same obstacles (Nasution, 2016). Teaching materials that are widely used in schools are teaching materials that only contain material that is not clearly spelled out and are not accompanied by pictures as an explanation of the material. One of the teaching materials commonly used by teachers and students is the Students' Worksheet (LKS). Worksheets that can guide students so they can easily understand the subject matter of mathematics, where there are several functions of using worksheet is a practical teaching material, helping students to add information about the concepts learned (Astari, 2017). Therefore, to improve students' critical thinking skills, a worksheet is needed that includes mathematics learning material, practice questions specifically designed to facilitate the critical thinking skills of class VIII students based on the Missouri Mathematics Project model using Think Talk Write Strategy. Based on the considerations above, it is necessary to compile and develop worksheet to facilitate students' critical mathematical thinking skills that are in accordance with the characteristics of junior high school students in Lubuklinggau. However, the worksheets that are developing today are still fairly practical and do not emphasize the process, so they cannot demand students to be active. Today, the availability of worksheets must contain a meaningful learning process and can support the achievement of mathematics learning goals that are in accordance with curriculum requirements, students' characteristics and demands for problem solving at the junior secondary level (Gazali, 2016). While the development of the curriculum is currently very much looking at the activeness of students in the learning process.

In learning mathematics, various learning models and learning strategies are very well applied in teaching and learning in class. Related to the learning model and learning strategies used by teachers in teaching, teachers tend to choose and use learning models and learning strategies that are appropriate and in accordance with the subject matter to be delivered. One of them is the MMP learning model and TTW strategy. This is in line with the opinion of Slavin \& Lake (Alba, Chotim, \& Junaedi, 2014) MMP learning model is a learning model designed to help teachers effectively use exercises to be able to make students get better achievements. According to Nugroho, Suparni, \& Nu'man (2012) that Missouri Mathematics Project (MMP) is one of the structured learning models as well as the Mathematics Teaching Structure. According to (Wahyuni \& Efuansyah, 2018) this MMP will be more effective if it is collaborated with learning strategies that are in line with it. One strategy that can be used to support the success of student learning is the Think-Talk-Write (TTW) strategy. The purpose of this study is to determine the feasibility of worksheets that are developed based on the Missouri Mathematics Project Learning Model using Think Talk Write Strategy using Research and Development research methodology.

\section{METHOD}

The type of research used in this study is development research (Development and Research) using 4-D development flow. According to (Tegeh, Jampel, \& Pudjawan, 2014) research and development methods (Research and Development) are strategies or research methods that are effective enough to improve learning practices. The 4-D channel adopts Thiagarajan, according to (Trianto, 2010) this development model consists of four phases, 
namely the 4-D development model (Define, Design, Develop, and Disseminate). The subjects in this study were students of class VIII SMPN 11 Lubuklinggau in the academic year 2018/2019 in Even Semester.

Define is the stage for defining and defining the requirements needed in learning development. This stage includes front-end analysis, learner analysis, concept analysis, task analysis and specifying instructional objectives. The next step is design, the design phase aims to design learning tools. Four steps are taken at this stage, namely criterion-test construction, media selection in accordance with the characteristics of the material and learning objectives, format selection, and initial design. The develop phase is the stage to produce product development which is carried out through two steps, namely: expert appraisal followed by revision and developmental testing. The last stage is disseminate, this stage includes validation testing, packaging, diffusion, and adoption.

The instrument used in this study was a worksheet validation sheet for material, media, and language validators to measure the validity of the Students' Worksheets that were developed, as well as the Practical sheets of students and teachers to see the practicality of using the Student Worksheets in the learning process. Questionnaire assessment is developed based on an evaluation component that includes Appropriateness Content, Appropriateness Presentation, Assessment Critical Thinking Ability. The worksheet assessment using the MMP Model uses the TTW strategy, Feasibility of Graphic, Language Assessment, Display, Presentation of Material, and The Benefits (Table $1)$.

Table 1. Indicator

\begin{tabular}{|c|c|c|}
\hline \multicolumn{2}{|r|}{ Aspects } & Indicators \\
\hline \multirow{10}{*}{$\begin{array}{l}\text { Material } \\
\text { Experts }\end{array}$} & \multirow{4}{*}{$\begin{array}{l}\text { Appropriateness } \\
\text { of Content }\end{array}$} & Material compatibility with SK and KD \\
\hline & & Material Accuracy \\
\hline & & Supporting learning material \\
\hline & & Updated Materials \\
\hline & \multirow{4}{*}{$\begin{array}{l}\text { Appropriateness } \\
\text { of Presentation }\end{array}$} & Presentation Techniques \\
\hline & & Supporting Presentation \\
\hline & & Learning Presentation \\
\hline & & Completeness of Presentation \\
\hline & Critical Thinking Ability Assessment & $\begin{array}{l}\text { The suitability of the questions with the indicators of } \\
\text { critical thinking skills }\end{array}$ \\
\hline & $\begin{array}{l}\text { The LKS assessment using the MMP } \\
\text { Model uses the TTW strategy }\end{array}$ & $\begin{array}{l}\text { The compatibility of LKS with MMP Model uses } \\
\text { TTW strategy }\end{array}$ \\
\hline \multirow{3}{*}{$\begin{array}{l}\text { Media } \\
\text { Experts }\end{array}$} & \multirow[t]{3}{*}{ Feasibility of Graphic } & LKS size \\
\hline & & LKS Cover Design \\
\hline & & Design Content LKS \\
\hline \multirow[t]{4}{*}{ Linguists } & Language & Straightforward \\
\hline & \multirow[t]{3}{*}{ Assessment } & Communicative \\
\hline & & Conformity with the level of development of students \\
\hline & & Tuning and integrated thought flow \\
\hline
\end{tabular}


84 Wahyuni, Efuansyah, \& Sukasno, Developing student worksheet based on missouri ...

Use of terms, symbols or icons

\begin{tabular}{|c|c|c|}
\hline & Aspects & Indicators \\
\hline Student & Display & Clarity of text \\
\hline & & Image clarity \\
\hline & & Eye catching image \\
\hline & & Suitability of the image with the material \\
\hline & Presentation of Material & Presentation of material \\
\hline & & Ease of understanding material \\
\hline & & Systematic accuracy of presentation of material \\
\hline & & Clarity of sentences \\
\hline & & Clarity of symbols and icons \\
\hline & & Clarity of terms \\
\hline & & Suitability of the example with the material \\
\hline & The Benefits & Ease of study \\
\hline & & $\begin{array}{l}\text { Interest in using teaching materials in the form of } \\
\text { student worksheets }\end{array}$ \\
\hline & & Increased learning motivation \\
\hline
\end{tabular}

Data that has been obtained through a questionnaire by expert assessment of products and student in the form of qualitative value will be converted into quantitative values Likert Scale (Table 2).

Table 2. Likert scale

\begin{tabular}{cc}
\hline Score & Criteria \\
\hline 5 & Excellent \\
4 & Good \\
3 & Enough \\
2 & Less \\
1 & Very Less \\
\hline
\end{tabular}

(Sugiyono, 2017)

From the data that has been collected, we calculate the average by the formula:

$$
\bar{X}=\frac{\sum_{i=1}^{n} X_{i}}{n}
$$

The data obtained from material expert, media expert, linguist, and student is transformed into qualitative values based on ideal assessment criteria. The ideal scoring criteria are shown in Table 3 (Aini, Masykur, Komarudin, 2018).

Table 3. The ideal scoring criteria

\begin{tabular}{cc}
\hline Average Interval Score & Category \\
\hline$x>4.8$ & Very Good \\
$3.6<x \leq 4.8$ & Good \\
$2.4<x \leq 3.6$ & Enough \\
$1.2<x \leq 2.4$ & Not Good
\end{tabular}


$x \leq 1.2 \quad$ Very Poor

\section{RESULTS AND DISCUSSION}

\subsection{Results}

\section{Define}

At the define phase, field observations and interviews with mathematics teachers of class VIII SMP N 11 Lubuklinggau were conducted to obtain the data needed for the definition process. The process of this stage is front-end analysis, learner analysis, concept analysis, task analysis, and specifying instructional objectives. In the front-end analysis, it was found that the average mathematics critical thinking ability of students of class VIII of SMP N 11 Lubuklinggau is still in the low category, students are not accustomed to answering non-routine questions that require higher levels of thinking. In the learner analysis, it was found that the average age of eighth grade students at SMP N 11 Lubuklinggau is at the age of 12-14 years, where at that age students still need a lot of guidance and assistance from their teacher. The results of the task analysis found that students of class VIII had used the 2013 curriculum in accordance with government recommendations.

Based on the 2013 curriculum, it was found that the material that students learned was cubes and cuboids. In the concept analysis stage, students must be able to master the material about the properties of cubes and cuboids, and students are able to make nets to build cubes and cuboids. Students must also be able to master the concept of cube and cuboid surface area along with the volume of cube and cuboid. Students must also be able to model mathematical forms from existing problems and be able to solve problems related to daily life. Whereas in specifying instructional objectives it was found that students after learning the material to build a flat side space using LKS to facilitate the ability to think critically mathematics can achieve predetermined competencies.

\section{Design}

The next phase is the Design phase, the results of the defining phase serve as a source of reference in making LKS to facilitate the ability to think critically mathematics. The things done at this stage are criterion-test construction, what is done is the preparation of instruments consisting of worksheet validity assessment instruments, worksheet practicality assessment instruments and mathematics critical thinking skills test instruments was done. The instrument preparation process pays attention to aspects of the content eligibility component, the feasibility of presentation, the aspects of indicators of critical mathematical thinking ability, conformity to the Missouri Mathematics Project learning model and Think Talk Write strategy, language feasibility, and the feasibility aspects of graphics in accordance with BSNP standards. Next is the format selection which consists of steps to compile the worksheet framework and compilation of the worksheet systematics. Next is designing first draft of worksheet to be developed. The following is the first draft of worksheet that was made (Figure 1, Figure 2, Figure 3). 

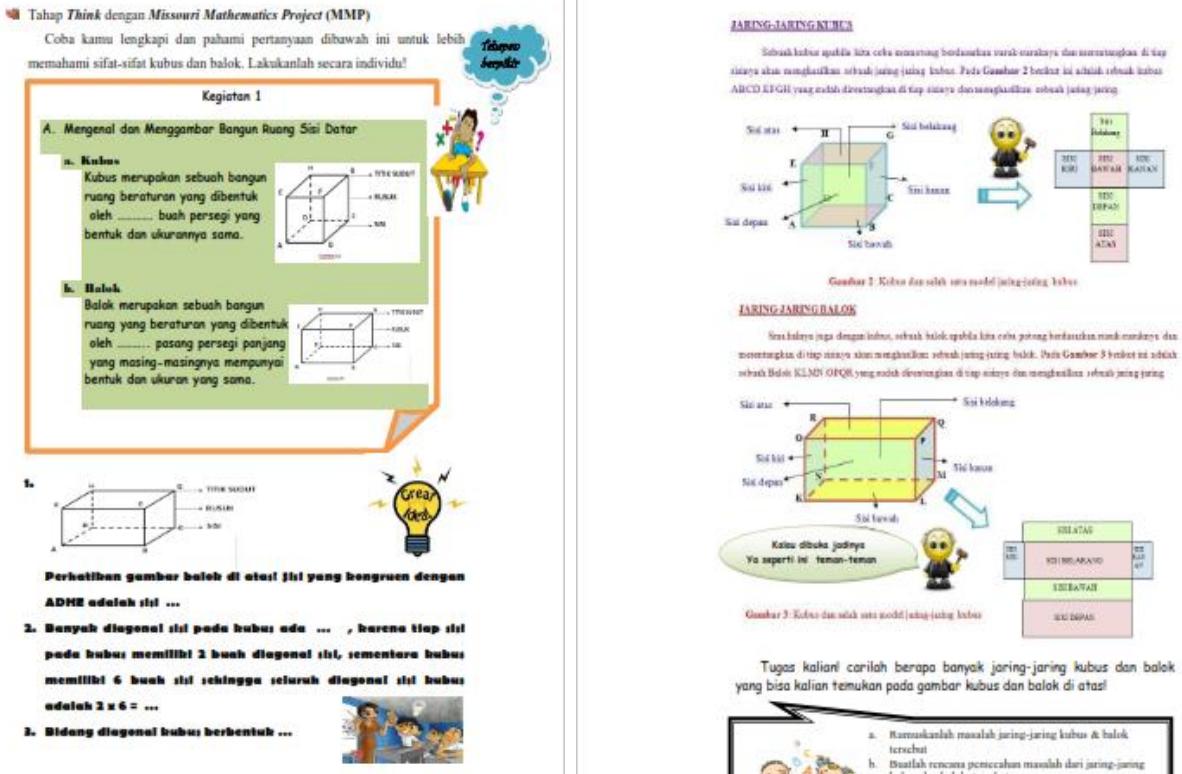

InEsedamsonues

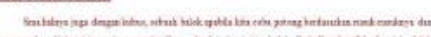

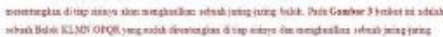
sim $\square$ sitedes
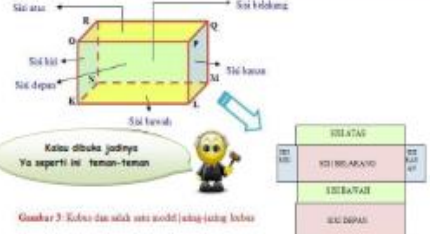

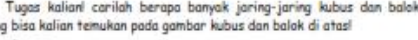

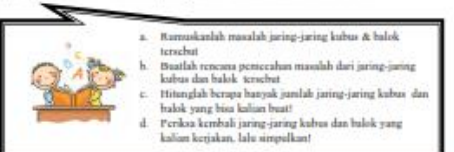

Figure 1. First display of material 1
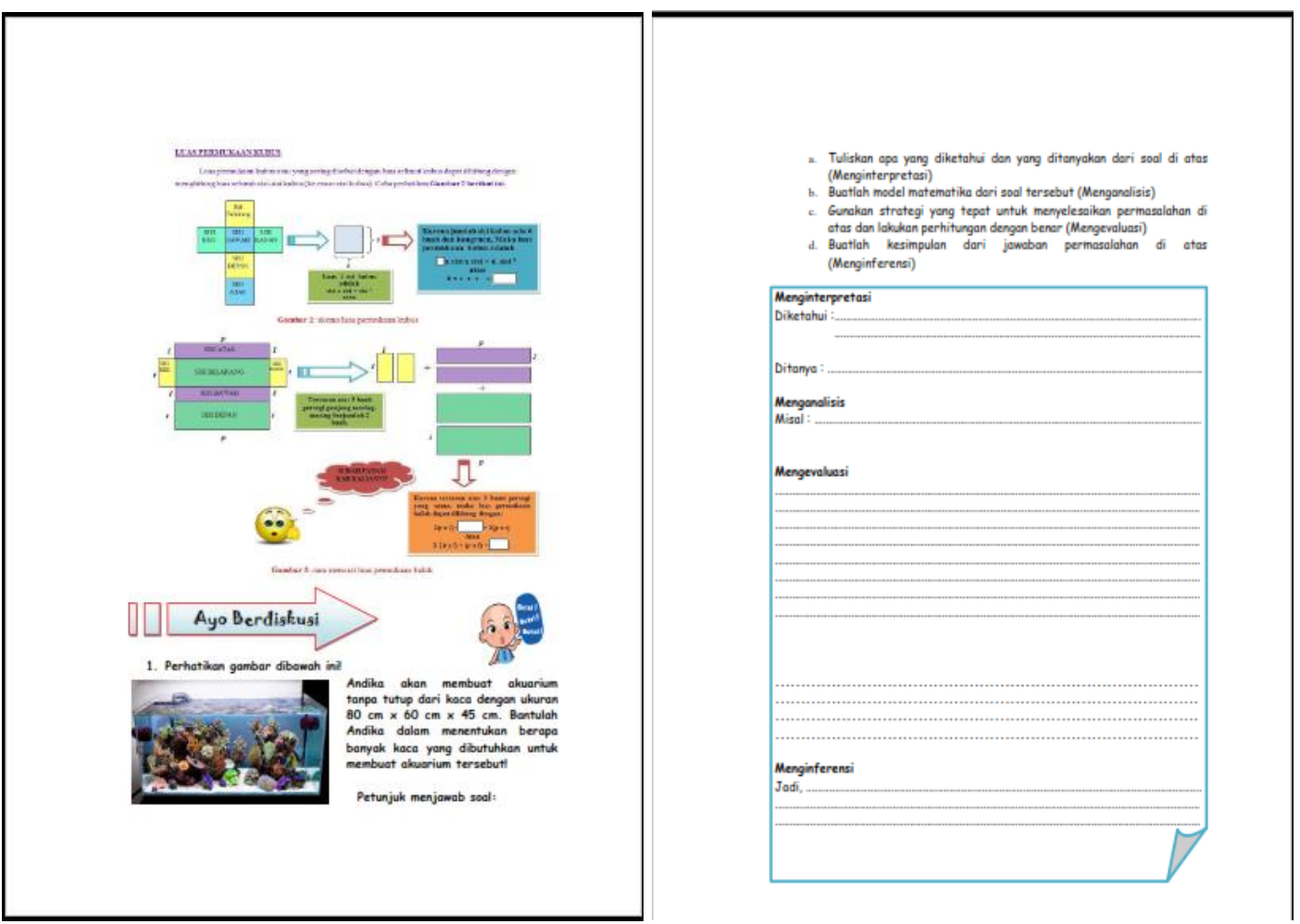

Figure 2. First display of material 2 


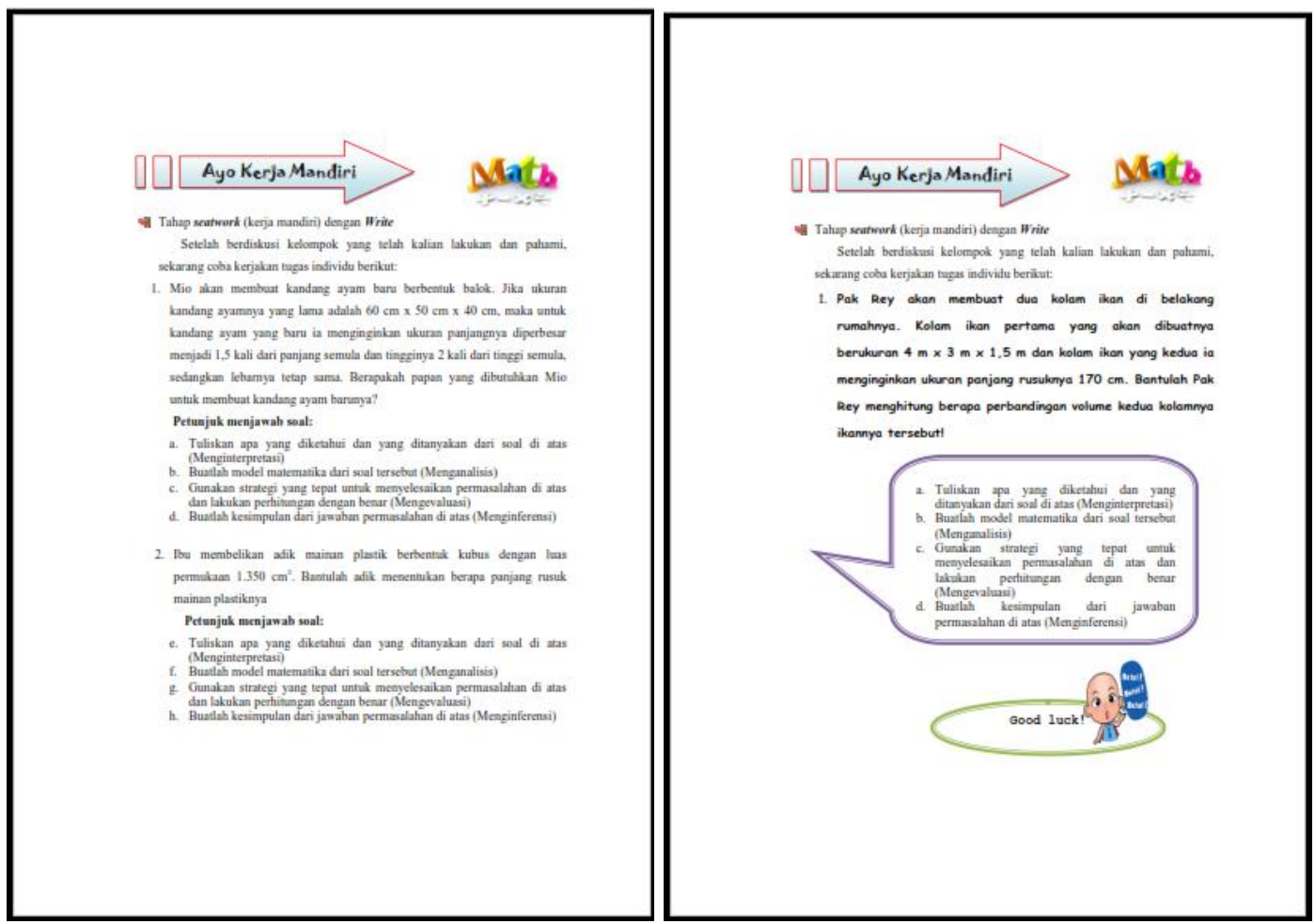

Figure 3. First display of MMP and TTW

\section{Develop}

\section{a. Expert Appraisal}

At the development phase, the worksheet which had been developed was validated by 3 validators consisting of material validation by Mr. Idul Adha, M.Pd., media validation by Mr. Dr. Dodik Mulyono, M.Pd., and language validation by Mrs. Dr. Rusmana Dewi, M.Pd. Based on the results of the validation analysis of 3, the average value obtained by the 3 validators is 3.99 (valid category).

Table 4. Recapitulation of assessment

\begin{tabular}{cccccc}
\hline No & Validator & Number of Items & $\begin{array}{c}\text { Score } \\
\text { obtained }\end{array}$ & $\begin{array}{c}\text { Average } \\
\text { score }\end{array}$ & Category \\
\hline 1 & Material Expert & 32 & 128 & 4.00 & Valid \\
2 & Media Expert & 25 & 102 & 4.08 & Valid \\
3 & Linguist & 11 & 43 & 3.91 & Valid \\
\hline & Total & $\mathbf{6 8}$ & $\mathbf{2 7 3}$ & $\mathbf{3 . 9 9}$ & Valid \\
\hline
\end{tabular}

Based on Table 4, the results of the recapitulation assessment above, it can be seen that the developed Students' Worksheet was Valid criteria in all aspects. This shows that the Student Worksheet that was developed is valid and feasible to be tested on students in the next phase. After the worksheet was declared valid, the worksheet was revised based on the comments and suggestions of the validators. The worksheet revision is based on the instructions and suggestions given by the validator through the validation assessment sheet. The following are comments and suggestions from the validator (Table 5). 
Table 5. Comments and suggestions of validators

\begin{tabular}{cl}
\hline Validator & \multicolumn{1}{c}{ Comments and Suggestions } \\
\hline Material & Clarify the instructions on the worksheet \\
\hline \multirow{3}{*}{ Media } & Pay attention to the word choice, sizes and colors \\
\cline { 2 - 2 } & $\begin{array}{l}\text { Select images based on the context of the material } \\
\text { bring the identity of worksheet on the cover }\end{array}$ \\
\hline \multirow{2}{*}{ Language } & $\begin{array}{l}\text { The language must be edited according to the command } \\
\text { sentence function. }\end{array}$ \\
\cline { 2 - 2 } & On the cover, put the identity for what school level and class \\
\hline
\end{tabular}

\section{b. Developmental Testing}

After the worksheet was revised, the next step was to conduct a small group trial consisting of 6 students consisting of 2 high-ability students, 2 medium-ability students and 2 low-ability students who were not as subject of product user trials. During the trial of the small group, the assessment sought responses and comments from target product users. The results of this small group trial are used to improve the worksheet. Based on the results of the calculation of small group trials, obtained 6 students who showed a positive assessment of the worksheet to facilitate students' critical thinking skills in mathematics.

After conducting a small group trial, the next stage is the field test stage in the actual class. The LKS trial was conducted in class VIII.B of SMP N 11 Lubuklinggau with a total of 23 students aiming to determine students' critical thinking skills. This trial was conducted 5 times in accordance with the learning syllabus used by SMP N 11 Lubuklinggau. After students have completed the learning process by using worksheets to facilitate students' critical mathematical thinking skills, students are asked to fill out a practical assessment sheet on the use of worksheets against worksheets developed. After students fill out the practicality assessment sheet, the sheet is analyzed. The analysis of assessment sheet to find out the practicalities of the worksheets developed. Based on the results of the practicality assessment sheet analysis, an average score 0.903 was obtained and is in the Very Practical category.

\section{Disseminate Phase}

The final phase of this development process is the Disseminate phase, at this phase the worksheet that has been improved according to the suggestions and comments at the time of development is carried out the packaging process of the worksheet so that it can be printed and distributed. After the worksheet is printed, the worksheet is disseminated so that it can be absorbed or understood by others and can be used in other classes. LKS is distributed to other grade, mathematics teachers of grade VII and IX, and the Principal of the SMP N 11 Lubuklinggau.

\subsection{Discussion}

Based on the description above, the research product obtained in the form of Student Worksheets based on the Missouri Mathematics Project Learning Model uses Think Talk Write Strategies to facilitate students' Critical Thinking abilities on the Cube and Cuboid material. The research product is in the form of Student Worksheets because in worksheet, students will get material, summaries, and assignments related to the material 
(Prabawati, Herman, \& Turmudi, 2019). Through learning by using this worksheet students are required to be active in the learning process so that the results obtained are in line with expectations, this is in line with the opinion of Pariska, Elniati, \& Syafriandi (2012) which states that through student worksheets students notice given the responsibility to complete tasks and feel must do it, especially if the teacher gives full attention to the results of their work, so students are actively involved in learning. Therefore, the teacher as a presenter must be able to choose a method or approach that is appropriate to the conditions of students' abilities in the classroom, including suitability in developing teaching materials / materials to support these learning activities (Gazali, 2016).

The result of Student Worksheet based on the Missouri Mathematics Project Learning Model using Think Talk Write Strategies on Cubes and Cuboids to facilitate the thinking skills of eighth grade students. According to Wahyuni \& Efuansyah (2018) this MMP will be more effective if it is collaborated with learning strategies that are in line with it. One strategy that can be used to support the success of student learning is the Think-Talk-Write (TTW) strategy. The developed LKS adopted a 4-D development procedure that went through four stages, the LKS was developed using the 2013 curriculum which was in accordance with government recommendations. At the junior high school stage students have been able to think abstractly, so students have been able to think formally, although they still need guidance and guidance from the teacher during the mathematics learning process in class. According to Ibda (2015) the level of cognitive development at the junior high school level is at the level of the formal operational stage. So that at this stage students have been able to think abstractly. With the worksheet that suits the needs of students, so as to be able to increase students' interest and motivation in learning mathematics, where there are several functions of using worksheet is a practical teaching material, helping students to add information about the concepts learned (Astari, 2017). Before LKS is ready to be used in learning in the classroom, worksheet must first go through the stages of product validation and development trials. Based on table 4, it can be seen that the worksheets validated by three experts are all in the valid category and the average value of the 3 validators is 3.99 and in the valid category. This is in line with the opinion of Haviz (2013), which states that the first aspect determining the quality of learning products is validity. After students have completed the learning process using worksheets to facilitate students' critical mathematical thinking skills, students are asked to fill out a practical assessment sheet on the use of worksheets against worksheets developed. After students fill out the practicality assessment sheet, the sheet is analyzed. The analysis of the assessment sheet to find out the practicalities of the worksheets developed. Based on the results of the practicality assessment sheet analysis, an average score obtained was 0.903 in the Very Practical category.

\section{CONCLUSION}

Based on the results of research and discussion above, the development of Student Worksheets based on the Missouri Mathematics Project Learning Model using Think Talk Write Strategy has been validated by material experts, media experts and linguists with Valid criteria and obtained an average score 3.99 and the results of the worksheet trial conducted at SMPN 11 Lubuklinggau in class VIII were in Very Practical criteria and an average score 0.903 was obtained.

\section{ACKNOWLEDGEMENTS}


The Authors would like to thank for the support to the Directorate of Research and Service Society, Directorate General Strengthening Research and Development Ministry of Research, Technology and Higher Education that has been support our research through Beginner Lecturer Research scheme.

\section{REFERENCES}

Aini, E. P., Masykur, R., \& Komarudin, K. (2018). Handout Matematika berbantuan Etnomatematika Berbasis Budaya Lokal. Desimal: Jurnal Matematika, 1(1), 73-79. https://doi.org/10.24042/djm.v1i1.1950

Alba, F., Chotim, M., \& Junaedi, I. (2014). Keefektifan model pembelajaran generatif dan missouri mathematics project terhadap kemampuan pemecahan masalah. UNNES Journal of Mathematics Education, 3(2), 107-112.

Astari, T. (2017). Pengembangan Lembar Kerja Siswa (LKS) berbasis Pendekatan Realistik untuk Meningkatkan Hasil Belajar Siswa SD Kelas IV. Jurnal Pelangi, 9(2), 150-160. https://doi.org/10.22202/jp.2017.v9i2.2050

Fithriyah, I., Sa'dijah, C., \& Sisworo. (2016). Analisis kemampuan berpikir kritis siswa kelas IX-D SMPN 17 malang. Konferensi Nasional Penelitian Matematika dan Pembelajarannya (KNPMP I), 580-590. Surakarta: Universitas Muhammadyah Surakarta.

Garrison, D. R., Anderson, T., \& Archer, W. (2001). Critical thinking, cognitive presence, and computer conferencing in distance education. American Journal of distance education, 15(1), 7-23. https://doi.org/10.1080/08923640109527071

Gazali, R. Y. (2016). Pengembangan bahan ajar matematika untuk siswa smp berasarkan teori belajar ausubel. PYTHAGORAS :Jurnal Pendidikan Matematika, 11(2), 182192. https://doi.org/10.21831/pg.v11i2.10644

Haviz, M. (2013). Research and development; penelitian di bidang kependidikan yang inovatif, produktif dan bermakna. Ta'dib, 16(1), 28-43. http://dx.doi.org/10.31958/jt.v16i1.235

Ibda, F. (2015). Perkembangan kognitif : Teori jean piaget. Jurnal Intelektualita, 3(1), $27-$ 38.

Ismaimuza, D. (2011). Kemampuan berpikir kritis matematis ditinjau dari pengetahuan awal siswa. Jurnal Pendidikan Matematika, 2(1), 11-20.

Jumaisyaroh, T., Napitupulu, E. E., \& Hasratuddin. (2014). peningkatan kemampuan berpikir kritis matematis dan kemandirian belajar siswa SMP melalui pembelajaran berbasis masalah. Kreano, https://doi.org/10.15294/kreano.v5i2.3325

Nasution, A. (2016). Pengembangan modul matematika berbasis masalah untuk meningkatkan kemampuan pemecahan masalah matematika siswa. REKOGNISI : Jurnal Pendidikan dan Kependidikan, 1(1), 47-63.

Nugroho, P. B., Suparni, \& Nu'man, M. (2012). Efektivitas model pembelajaran missouri mathematics project (MMP) dengan metode talking stick dan penemuan terbimbing terhadap hasil belajar matematika siswa. Seminar Nasional Matematika dan Pendidikan Matematika, 681-688. Yogyakarta: Pendidikan Matematika FMIPA UNY. 
Pariska, I. S., Elniati, S., \& Syafriandi, S. (2012). Pengembangan lembar kerja siswa matematika berbasis masalah. Jurnal Pendidikan Matematika, 1(1), 75-80.

Prabawati, M. N., Herman, T., \& Turmudi, T. (2019). Pengembangan Lembar Kerja Siswa Berbasis Masalah dengan Strategi Heuristic untuk Meningkatkan Kemampuan Literasi Matematis. Mosharafa: Jurnal Pendidikan Matematika, 8(1), 37-48. https://doi.org/10.31980/mosharafa.v8i1.383

Sandiyanti, A. (2018). Pengembangan modul bilingual bergambar berbasis quantum learning pada materi peluang. Desimal: Jurnal Matematika, 1(2), 157-164. https://doi.org/10.24042/djm.v1i2.2280

Somakim, S. (2011). Peningkatan kemampuan berpikir kritis matematis siswa sekolah menengah pertama dengan penggunaan pendidikan matematika realistik. Majalah Ilmiah Jurusan PMIPA FKIP Unsri, 14(1), 42-48.

Sugiyono. (2017). Metode Penelitian dan Pengembangan (Research and Development/ $R \& D)$. Bandung: Alfabeta.

Tegeh, I. J., Jampel, I. N., \& Pudjawan, K. (2014). Model Penelitian Pengembangan. Yogyakarta: Graha Ilmu.

Trianto. (2010). Model Pembelajaran Terpadu. Jakarta: Bumi Aksara.

Wahyuni, R., \& Efuansyah. (2018). Model pembelajaran missouri mathematics project (MMP) menggunakan strategi think talk write (TTW) terhadap kemampuan berpikir kritis dan kemampuan pemecahan masalah. JNPM (Jurnal Nasional Pendidikan Matematika), 2(1), 24-36. http://dx.doi.org/10.33603/jnpm.v2i1.778 
